\title{
POKLICNA IZGORELOST ALI ZAVZETOST ZA DELO, TO JE ZDAJ VPRAŠANJE Osebni in skupinski izobraževalni moduli za preprečevanje poklicne izgorelosti (2. del)
}

Andreja

Pšeničny, univ, dipl, psih, doc. dr. Dušana Findeisen, Filozofska fakulteta Univerze $v$ Ljubljani

\section{POVZETEK}

Raziskavo sta avtorici posvetili preučevanju potreb po varovanju zaposlenih pred poklicno izgorelostjo, hkrati pa tudi spodbujanju njihove zavzetosti za delo. Podjetje, ki se zaveda pomena svojih virov, lahko v enem in drugem primeru s podobnimi izobraževalnimi vsebinami in postopki oplemeniti svoj najpomembnejši vir-ljudi. Avtorici ugotavljata, da v zvezi s poklicno izgorelostjo danes ni več poudarek na preučevanju osebnostnih lastnosti za delo »preveč vnetih ljudi, marveč predusem na proučevanju delovnega okolja in psihološkil delovnih okoliščin v podjetju. Poklicno izgorelost lahko preprečimo tudi z znanstveno utemeljeno organiziranostjo podjetja ali ustanove; takšno, ki spodbuja formalne in neformalne komunikacijske okoliščine, pozitivne medsebojne in kolektivne odnose ter druge ugodne psihološke delovne okoliščine. Izobraževanje za prepoznavanje in preprečevanje poklicne izgorelosti na eni strani ter izobraževanje za spodbujanje zavzetosti za delo na drugi strani je posvečeno posameznikom, podjetjem, strokovni in siroki javnosti.

Ključne besede: poklicna izgorelost, burnout, zavzetost za delo, zaposleni, psihološke delovne okoliščine, psihološki pogoji dela, organiziranost podjetja, delovno okolje, medsebojni odnosi, identiteta na delovnem mestu, varstvo pri delu, izobraževanje odraslih

\section{$\mathrm{P}$} mo kot psihološki sindrom, ki je kumulativni odgovor na dolgotrajne neustrezne psihološke okoliščine dela. Poklicno izgorela oseba izgubi psihično in telesno moč, Pretirano ali povsem ji upade motivacija za delo. Je izčrpana in zato negativna do različnih vidikov dela, ki ga opravlja na delovnem mestu. V medsebojnih odnosih je takšna oseba prezirljiva, s čimer brani svojo psihično integriteto. Počuti se nesposobna, občutek ima, da ne dosega, kar želi, da ni produktivnà.

Poklicno izgorelost lahko preprečimo na različne načine in tudi, tako se $\mathrm{zdi}, \mathrm{z}$ znanstveno utemeljeno organiziranostjo podjetja. Ta naj spodbuja formalne in neformalne komunikacijske okoliščine v podjetju in gradi medsebojne odnose. Del organiziranih kolektivnih odnosov je tudi permanentno izobraževanje zaposlenih, ki ima lahko trajne posledice za stil odnosov v podjetju. Izobraževanje v podjetju je namreč tudi učenje medsebojnih odno- 
sov. Po zaključenem izobraževanju zaposleni hierarhijo $\mathrm{v}$ odnosih in povezovanje zaposlenih v tandeme laže prenesejo. Pa ne samo to. Udeležba $v$ izobraževanju lahko okrepi občutek zadovoljstva $\mathrm{z}$ delom in pripadnosti podjetju. Lahko vpliva na splošno zavzetost za delo, na medsebojne odnose in psihološke delovne okoliščine nasploh.

Izobraževanje za prepoznavanje in preprečevanje poklicne izgorelosti je namenjeno tako posamezniku kakor tudi podjetjem. Temu so podrejene tudi izobraževalne vsebine. Ima

Poklicno izgorelost lahko preprečimo z znanstveno utemeljeno organiziranostjo podjetja. več ciljev, denimo (1) analizirati psihološke dejavnike dela $v$ podjetju, (2) prepoznati zgodnje faze poklicne izgorelosti pri sebi in sodelavcih ter jo preprečiti, (3) zadržati najboljše delavce na delovnem mestu, (4) ohranjati in razvijati motiviranost in zavzetost za delo pri zaposlenih, (5) zmanjšati stroške poslovanja, (6) povečati konkurenčnost podjetja. Metode so delo s teoretičnimi viri, analiza osebnega stanja in stanja v podjetju, izkustveno usposabljanje. Za naštete ciljne skupine je potrebno pripraviti programe, ki imajo skupno vsebinsko jedro, ob tem pa nanizati posamezne module, primerne za posameznike oziroma posamezne ciljne skupine glede na njihove predhodno analizirane skupne potrebe.

\section{METODOLOGIJA}

Raziskava je aplikativne narave, utemeljena na pragmatičnem in teoretičnem konceptualnem okviru. Cilj raziskave je odkriti vsebine, ki bi lahko tvorile jedro izobraževalnih programov oziroma posamezne izobraževalne module za preprečevanje poklicne izgorelosti in hkrati za spodbujanje zavzetosti za delo. Izobraževalni program bomo namenili preprečevanju poklicne izgorelosti, pa tudi razvijanju zavzetosti za delo v podjetju. Ker je raziskava utemeljena na pragmatičnem konceptualnem okviru, na naših potrebah in na potrebah podjetij, za katera razvijamo izobraževalne programe, smo analizirali tudi stanje $\mathrm{v}$ izbranem podjetju, kjer je danes devetnajst zaposlenih. Śe pred petimi leti so bili tam zaposleni le trije. Z večanjem števila zaposlenih je bilo potrebno podjetje organizirati drugače. Tudi obseg dela hitro raste. Delovne okoliščine se spreminjajo. Podjetje sledi razvoju tehnologije na svojem področju.

Zanimala nas je organiziranost podjetja: področja dela, kjer se lahko rojevajo neugodne psihološke delovne okoliščine, komunikacijske okoliščine v podjetju, stanje medsebojnih

Izobraževanje za preprečevanje izgorelosti na delovnem mestu lahko podjetje nameni predvsem vodilnim delavcem in tistim zaposlenim, za katere vodstvo misli, da jih nikakor ne bi želelo izgubiti, pa naj gre za vodilne kadre ali druge zaposlene. Pomembno pa je, da izobraževanje za ti dve ciljni skupini teče ločeno: na eni strani za vodstvo in vodilne kadre, na drugi za zaposlene. Hkrati bi veljalo s pomočjo javne kampanje povečati védenje o poklicni izgorelosti tudi pri socialnih partnerjih, zakonodajalcih, strokovni in široki javnosti. Za široko javnost je poleg običajnih izobraževalnih kanalov in oblik, kot so radijske in televizijske oddaje, okrogle mize in predavanja, sporočila po mobilnem telefonu, na katera se oseba predhodno naroči itd., potrebno ustvariti predvsem spletno stran, kjer obiskovalci lahko izvedo temeljna dejstva o poklicni izgorelosti. Tam se lahko pridružijo diskusijski skupini, najdejo novice o obvladovanju poklicne izgorelosti, izdelajo svoj psihološki in delovni profil s primerjanjem svojega začetnega profila s kontrolnim profilom. Spletna stran ima namen spodbuditi nastanek skupnosti, ki si želi delati bolje in v boljših psiholoških razmerah. 
in kolektivnih odnosov. Še več, naša hipoteza je bila, da tudi bolj evolutivna in prožna delovna mesta, evolutivnejši in prožnejši delovni timi, kakršne zahteva sodobno podjetje, narekujejo veliko prilagajanja, kar poleg drugih okoliščin lahko poveča tveganje za nastanek poklicne izgorelosti.

Uporabilli smo metodo participativnega opazovanja. Uvedli smo tudi več anketnih in pol strukturiranih vprašalnikov. Nekatere smo povzeli po teoretičnih virih in jih modificirali za svojo uporabo. Druge spet smo pripravili sami za pilotno raziskovanje, $v$ času pilotnega raziskovanja pa smo jih večkrat popravili in dopolnili. Izkazalo se je namreč, da so bila nekatera od naših vprašanj za vprašane nesmiselna ali pa so jih razumeli drugače kot mi. Razdelili smo jih respondentom, zaposlenim v izbranem podjetju, tj. marketinški agenciji, kjer smo opravljali raziskavo. Vsi so bili moškega spola, razen ene ženske, vși višje in visoko izobraženi. Starostni razpon je bil od 25 do 45 let. Posamezne sklope vprašanj smo oblikovali tako, da bi dobili odgovore predvsem na tri raziskovalna vprašanja:

- Kako naj bo podjetje organizirano, da bi lahko nudilo več in predvsem boljših formalnih in neformalnih priložnosti za spodbudno komunikacijo?

- Katere vsebine naj vsebuje izobraževalni program za preprečevanje poklicne izgorelosti oziroma burnouta?

- Kako v podjetju ustvariti ustrezne psihološke delovne okoliščine?

\section{IZOBRAŽEVALNE VSEBINE IN MODULI ZA PREPREČIEVANJE POKLICNE IZGORELOSTI}

Preučevanje strokovne literature, izkušnje ene od avtoric in izkušnje nekaterih drugih, ki so preživeli poklicno izgorelost, ter izsledki te raziskave so pokazali, da je poklicna izgorelost nedvomno močno oseben pojav, ki zahteva osebno obravnavo, ko se znajdemo $v$ za- dnji fazi procesa izgorevanja. Vendarle pa je pred tem, v zgodnjih fazah, ki jih denimo na Finskem in Veliki Britaniji doživi približno polovica zaposlenih, mogoče udeležence izobraževanja za preprečevanje poklicne izgorelosti in/ali spodbujanje zavzetosti za delo, vključiti $v$ nekatere jedrne vsebinske module, ki ustrezajo njihovim skupnim potrebam.

\section{PREPOZNAVANIE POKLICNE IZGORELOSTI, NJENIH VZROKOV, SIMPTOMOV IN POSLEDIC}

J. D. Reynaud (v Sainsaulieu, 1988, str. 4) je že okrog leta 1960 opozoril, da «so zaposleni $\checkmark$ podjetju žejni neformalnih odnosov«, kar pomeni, da so odnosi v podjetju pomembni za posameznike in skupine ter da organizacija odnosov v podjetju ne more biti podrejena le ekonomskim zapovedim. Formalni in neformalni odnosi so lahko celo vir »sreče« ali »nesreče « na delovnem mestu ali pa zaposlene potisnejo $\mathrm{v}$ umik od dela. V slednjem primeru se zaposleni pred delom varuje-

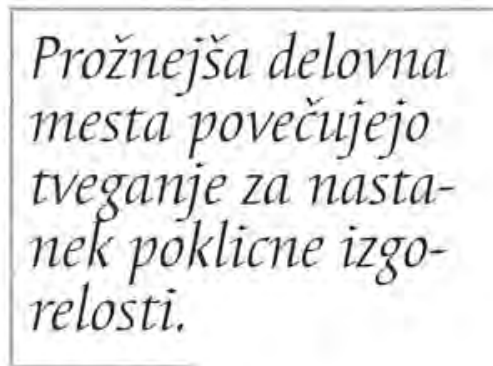
jo, doživljajo ga kot nujno zlo in nič več. Še več, francoski raziskovalci so $\mathrm{z}$ longitudinalno raziskavo preučevali, koliko so zaposleni srečni na delovnem mestu. Ugotovili so, da je delo za »srečne« zaposlene strast, avantura, nekaj, kar imajo radi. Na delovnem mestu ti zaposleni doživljajo pravične odnoșe. V delo vlagajo velik del sebe, vendar iz tega dobijo nekaj zase; dobro so plačani, ali so plačani dovolj, upoštevajo jih, vzpostavili so dobro ravnovesje med tem, kar dajejo in kar dobivajo, med delovnim življenjem in zasebnim Življenjem. Dobro se razumejo s sodelavci, predpostavljenimi, podrejenimi. Med sodelavci imajo prijatelje. Doživljajo občutek pravičnosti (Baudelot, C., Gollac, M., idr., 


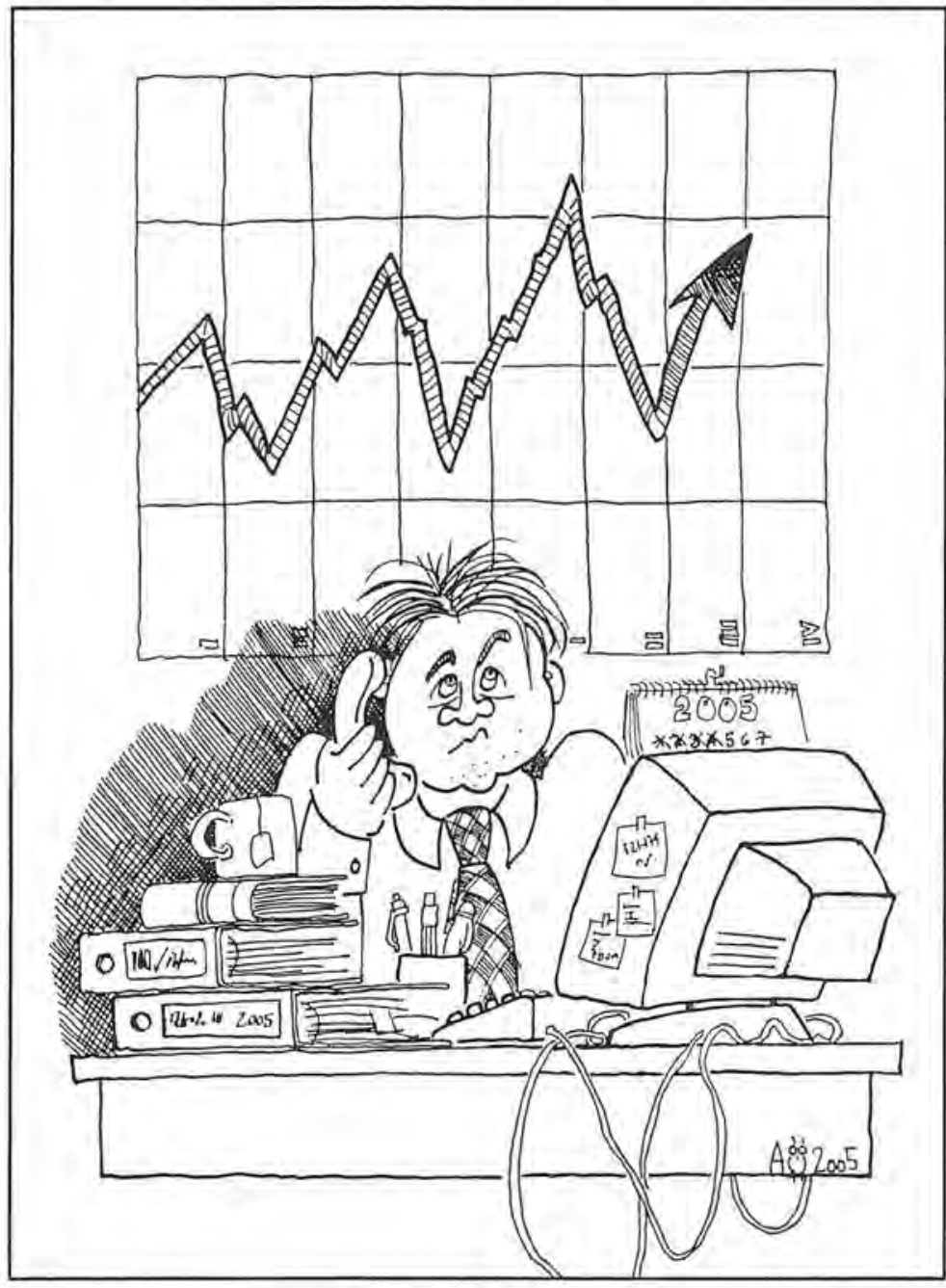

2003). Zdi se, da je sreča na delovnem mestu $v$ mnogočem vprašanje recipročnih odnosov na delovnem mestu.

Več desetletij so tako izraz poklicna izgorelost uporabljali predvsem zato, da bi opisali razkorak, ki nastane med delavčevimi pričakovanji in tem, kar mu delovno mesto ponuja. $\mathrm{V}$ glavnem gre zgodba takole: delavec je delo prevzel, imel je pozitivna pričakovanja, bil je navdušen, postavil si je cilje in želel si je biti uspešen pri opravljanju dela. Skozi čas pa so se stvari spremenile in močno se je utrudil. Zdaj ga obvladujejo čustva frustriranosti, jeze, prezira, oběutek neučinkovitosti in neuspešnosti. Začetna vnema in ogenj sta popustila. Zdaj
Udeleženci izobraževanja za preprečevanje poklicne izgorelosti in za razvoj zavzetosti na delovnem mestu tako poskušajo ugotoviti, v kakšnem razmerju so $\mathrm{z}$ delom, ki ga opravljajo: ali je to razmerje recipročno ali ne in kaj bi bilo moč storiti, da se stanje popravi. Dolgotrajna nerecipročnost je namreč eden od bistvenih vzrokov za nastanek poklicne izgorelosti. Pomembno je tudi, da se udeleženci izobraževanja najprej seznanjjo s teoretičnimi okviri za razumevanje poklicne izgorelosti in delovne zavzetosti: da spoznajo različne vzroke pa tudi simptome in posledice stanja poklicne izgorelosti ter hkrati prepoznajo vzroke in značilnosti delovne zavzetosti.

je prizadeto tudi njegovo osebno in socialno življenje na delovnem mestu. Takšno stanje delavec »plačuje «, "plačujejo « pa ga tudi sodelavci in vsa delovna organizacija. Nekateri delavei po delovni izgorelosti organizacijo in delovno mesto zapustijo. Drugi spet ostanejo. a na istem delovnem mestu ne bodo dali več veliko od sebe.

Poleg tega je dolgo veljalo, da je poklicna izgorelost predvsem vprašanje posamezne osebe. Ta naj bi bila bolj občutljiva kakor druge. Raziskave so sicer pokazale povezavo med tveganjem za nastanek poklicne izgorelosti ter osebnostnimi lastnostmi, kot so introvertnost, nevroticizem, nezaupanje vase. Kljub temu pa se je v zadnjem času preučevanje vzrokov poklicne izgorelosti premaknilo od "preobčutljivega« posameznika predvsem $\mathrm{k}$ psihološkim delovnim okoliščinam. Te pa soustvarja podjetje. Vodstvo podjetij lahko vpliva nanje in vodstvo podjetij lahko zaposlene tudi zaščiti pred nevarnostjo pokliene izgorelosti, lahko pa tudi ustvari takšne okoliščine, v katerih se bo zavzetost zaposlenih za delo moěno povečala. Tako se v zadnjem času vrstijo posvetovanja vodilnih delavcev prav na to temo. Četudi podjetja velikokrat zanima le preživetje 
in jim je vsakršno razmišljanje o prihodnosti odveč, pa se vendarle vse bolj zavedajo, da so ljudje njihov edini vir, ki ga še lahko oplemenitijo, da bo dajal več. Edini vir, ki jih lahko naredi konkurenčne v globbalni tekmi.'

$\mathrm{V}$ povezavi s poklicno izgorelostjo se pojavljajo različni simptomi, ki so čustvene, kognitivne, vedenjske in telesne narave. V modulu, ki je namenjen prepoznavanju simptomov poklicne izgorelosti, se jim je treba poglobljeno posvetiti, kajti le tako bodo udeleženci sposobni prepoznati nevarnost, ki jim grozi. Vedeli bodo, da ne gre zgolj za posledice napornega dela, takšne, ki jih je moč izbrisati s počitkom ali počitnicami. Š več, spoznali bodo, kako nevarno je poklicno izgorelost zamenjati s stresom na delovnem mestu. Stres in poklicna izgorelost sta namreč povsem različna, četudi med njima obstaja tesna zveza.

Pri poklicni izgorelosti je poudarek bolj na procesu nastajanja bolezenskega stanja psihološke načetosti in na psiholoških ter družbenih posledicah izpostavljenosti kot pa na fizičnih posledicah, ki nas zanimajo pri stresu. Ker je izgorelost dolgotrajno nastajajoč odgovor na trajne pritiske na delovnem mestu, je stanje izgorelosti lahko dlje časa navidez enako, brez sprememb. Zato govorimo o različnih fazah nastajanja izgorelosti. Vsaka faza lahko traja zelo dolgo in napoveduje naslednjo. Do neke mere pa je nepopravljiva le zadnja.

\section{VPLIV ORGANIZIRANOSTI PODJETIJ IN DRUGIH EKONOMSIKIH STRUIKTUR} NA MEDSEBOJNE ODNOSE IN DRUGE PSIHOLOŠKE DELOVNE
OKOLIŠČINE

Večina izobraževalnega programa je namenjena preučevanju medsebojnih odnosov $v$ podjetju in vplivov nanje. Institucionalna oblika podjetja in delovne razmere, ki vladajo v njem, lahko močno vplivajo na odnose in na njih temelječo osebno identiteto zaposlenih.

Osebno identiteto pojmujemo kot dinamičen konstrukt v delu človekove zavesti, konstrukt o samem sebi, ki nastaja z medosebnimi odnosi, govorno komunikacijo in socialnimi izkušnjami (Doron, R., Parot, F., 1991, str. 360). Tako odnosi $\checkmark$ podjetju vplivajo na to, koliko so zaposleni produktivni, vrhu tega pa tudi na to, kako razumejo sami sebe in koliko

Zaposleni $v$ podjetju so žejni neformalnih odnosov. se spoštujejo. Na to, kaj in kako delajo danes, ter na to, kaj in kako bodo delali v prihodnje. Neustrezni medsebojni odnosi in prizadeta osebna identiteta zaposlenih so pomemben vzrok poklicne izgorelosti oziroma nasprotno - zavzetosti za delo.

Delovne navade, načini razmišljanja in delovanja so bili še pred malo več kot stoletjem povsem drugače organizirani kakor danes. Spomnimo se samo obrtnikov in mojstrov, $\mathrm{ki}$ so zaposlovali vajence. Poleg zaposlitve so jih hranili, ogrevali in jim prali perilo. Vajenci so jedli za isto mizo $\mathrm{z}$ mojstrom in njegovo družino. Takrat so bili proizvodni odnosi $v$ tesni povezavi $z$ institucijo družine, obrti in ceha. ${ }^{2}$ Tudi v industrijskih podjetjih so bili odnosi zaradi industrijskega načina proizvajanja organizirani drugače kakor danes. $\mathrm{Pa}$ vendar so že na višku industrijskega obdobja, v začetku 60-ih let, ugotovili, da je podjetje okolje,

Kdo je odgovoren za poklicno izgorelost; 'preobčutljiv' posameznik ali organizacija? kjer se zaposleni trudijo in se odnosi odvijajo še vse drugače, kot je predvideno s formalnim organigramom, Frederick Winslow Taylor, oče taylorizma oziroma »sistema nalog «, razmišlja o tem, da so interesi delodajalcev in delojemalcev pravzaprav isti in si ne nasprotujejo. Naloga vodenja je, da ustvari skar se da veliko blagostanje za delodajalca in kar se da veliko blagostanje za zaposlenega«. Blagostanje zaposlenega pa ne pomeni samo dobre plače, marveč tudi, da lahko čimbolj razvije svoje sposobnosti in jih tudi uporabi pri delu,

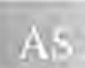


V družini, obrtnih, cehovskih in industrijskih skupnostih so bili torej odnosi organizirani na povsem drugačen način, kot so organizirani danes $\mathrm{v}$ postindustrijskem organiziranem delu. Podjetja hitro rastejo tako tehnološko kot po obsegu dela. Se združujejo, selijo v druge kraje in države, selijo se v druge kulture. Delovne razmere se spreminjajo in podjetja vedno znova potrebujejo drugačno organiziranost. Ta vpliva na medsebojne odnose $v$ podjetju. ${ }^{3}$ Zato je pomembno, da se tudi v izobraževanju za preprečevanje poklicne izgorelosti posvetimo posledicam organiziranosti ekonomskih struktur.

ki takšne sposobnosti zahteva. To je tudi v dobro delodajalca, saj se bo tako povečala konkurenčnost podjetja (Taylor, 1967, str. 9-12). Taylor je prvi razmišljal o tem, da je v dobro delodajalca in zaposlenega, da se učita, izobražujeta in razvijata. V zvezi z izobraževanjem vidi predvsem povečano produktivnost, ne uvidi pa pomena izobraževanja za odnose $\checkmark$ podjetju, oziroma, danes bi rekli, za ustvarjanje psiholoških delovnih okoliščin.

Organiziranost podjetja vpliva na kognitivne

\section{Odnosi v podjetju se vselej nepred- vidljivo razvijajo.} strukture pa tudi na kolektivne navade zaposlenih. ${ }^{4}$ Kako zaposleni razmišljajo, kakšne kolektivne navade imajo, kako delujejo - vse to in Še marsikaj drugega je del kulture podjetja, nastajajoče kot posledice medsebojnega vplivanja osebnih kultur, ki jih zaposleni prinesejo $\mathrm{v}$ podjetje. $\mathrm{V}$ delovnem okolju ti preizkušajo vrednost norm in vrednot, ki so jih pridobili poprej. V podjetje lahko vstopijo $\mathrm{z}$ mislijo, da morajo biti pogumni, da se morajo truditi, da morajo biti poklicno pošteni. Ali da je, denimo poklic, ki so si ga izbrali, lep in da morajo kaj pomembnega doseči z lastnim trudom. Te vrednote pa so lahko $v$ nasprotju s prepričanjem v podjetju, da je pomembnejša čimboljša formalna izobrazba zaposlenih, da se za vsako ceno ustvari dobiček itd. Podjetje je lahko »polno predsodkov proti ljudem srednje starosti, lahko zanika vrednost preteklih izkušenj zaposlenih« (Sennett, 1998, str. 91).
Skratka, podjetje ima lahko povsem drugačne vrednote od vrednot zaposlenih, kar bistveno oblikuje psihološke delovne okoliščine in odnose $v$ podjetju.

Okoliščine, v katerih zaposleni preizkušajo norme in vrednote, $k$ i so jih pridobili v druži$\mathrm{ni}$ in šoli, $\mathrm{v}$ lokalnem ali nacionalnem in internacionalnem okolju, omogočajo osvajanje novih idej in novih vrednot. Pravzaprav je v podjetju vsak dan na preizkušnji vse, kar smo pridobili pred nastopom službe in drugod (prav tam, str. 10). Kdor poskuša analizirati organizacijo podjetja in odnose $v$ njem, bi moral $v$ najboljšem primeru sodelovati $z$ etnologom, ki bi preučil navade različnih socioprofesionalnih kategorij, v katere se uvrščajo zaposleni. Gre za subkulture na delovnem mestu, s katerimi je moč razložiti medsebojna in kolektivna dejanja $v$ podjetju.

Odnosi v podjetju (1) podpirajo funkcije podjetja (proizvodnja, ponujanje storitev itd.) in (2) izkazujejo socialno borbo med zaposlenimi (ti potrjujejo osebnost, se borijo za položaj ipd.), imajo pa še eno razsežnost (3), tj. vsakdanje odnose zaposlenih pri delu, kjer se prepletejo odnosi v podporo funkcijam podjetja, medsebojne in kolektivne odnose. Vse skupaj daje svetu dela nov pomen. Ker postajajo odnosi na delovnem mestu tako kompleksni in se danes delu posvečamo več kakor osem ur, nastanejo v primeru dolgoletnih nerecipročnih odnosov, v katere človek več vlaga, kot iz njih prejema, neugodne psihološke delovne okoliščine, ki vplivajo na vedenje zaposlenih in vodijo $\mathrm{v}$ poklicno izgorelost.

Vpliv vseh, ne zgolj psiholoških delovnih okoliščin na obnašanje posameznikov in kolektiva je splošno sprejeto dejstvo. Podjeten duh in zavzetost za delovne naloge tako nista odvisna le od zunanjih dejavnikov, kot so fizično okolje, plača, varnost ipd., marveč tudi od intrinzičnih dejavnikov delovnih nalog, kot so znanje, raznolikost delovnih operacij in širše gledano tudi organiziranost delovnih mest in delovnih timov. ${ }^{5}$ Delovne zmožnosti, 
ustvarjalnost in vodenje so odvisni od stanja organizacijskih struktur; formalnih in neformalnih odnosov $v$ podjetju (Sainsaulieu, 1988, str. 57).

Pomembna psihološka delovna okoliščina so tudi komunikacijske okoliščine v podjetju. Zdi se, da so zaposleni v svojem načinu razmisljanja, simboliziranja in interpretiranja svojih izkušenj ali izkušenj drugih močno pod njihovim vplivom. $V$ nekem uspešnem podjetju, navaja Sainsaulieu, so tako uvedli naslednje spremembe, ki so imele pozitivne učinke na komunikacijo in posledične psihološke delovne okoliščine $v$ podjetju: organizirali so notranje izobraževanje, kjer je prihajalo do komunikacije med zaposlenimi. Ce je nekdo opravil usposabljanje, je napredoval. Vodilnim so naročili, naj sami prerazporedijo zaposlene, ki so uspešno opravili kakšen izpit, na delovna mesta, kjer bodo koristnejši. Zaposleni so pričeli prejemati denarno podporo in v času izobraževanja jim ni bilo treba delati. Uvedli so redne mesečne, več ur trajajoče sestanke. Tiskali so najpomembnejše informacije, jih za vse zaposlene obesili na oglasne deske. Zaposleni so prejeli veliko dobro oblikovanih informacij o podjetju. Enkrat mesečno je vodja proizvodnje sklical vodje delovnih ekip za več ur. Pogovarjali so se o tehniki, finančni uspešnosti podjetja, novih programih in proizvodih. Povzetek vseh informacij so obesili na vidno mesto, da so ga lahko prebrali ysi zaposleni. Enkrat na tri mesece je takšno srečanje potekalo med delovnim časom in za vse zaposlene. To podjetje je postalo zgled za mnoge druge v regiji. Občutno je povečalo konkurenčnost in dohodek (Sainsaulieu, 1988).

Tiste, ki raziskujejo preprečevanje poklicne izgorelosti vodilnih delavcev in zaposlenih, zanimajo načela regulacije socialnega sistema odnosov pomembnih nosilcev podjetja. $\mathrm{Na}$ regulacijo odnosov in posledične komunikacijske okoliščine $v$ podjetju vplivajo organiziranost podjetja pa tudi zunanje okoliščine,
Georges Friedman trdi, da razen situacij $v$ delovni organizaciji tudi organizacijski sistem dela lahko vpliva na vedenje zaposlenih. Zaposlene lahko vodi $\mathrm{k}$ večji delovni vnemi, lahko jih po nepotrebnem utruja, frustrira, jih privede celo $v$ poklicno izgorelost. ${ }^{6}$ Seveda mora biti vodstvo podjetij humanistično, saj lahko $\mathrm{v}$ nasprotnem primeru poznavanje vplivov znanstveno utemeljene organiziranosti podjetja na vedenje zaposlenih pelje v zlorabo. V osvetlitev te trditve navajamo primer nekega ameriškega podjetja, ki je spodbujalo zasvojenost zaposlenih z delom, nekatere med njimi pripeljalo $\mathrm{v}$ stanje poklicne izgorelosti in jih nato odpustilo.

kot so izjemno hitre gospodarske, tehnološke in družbene spremembe. Tako smo tudi v izobraževalnem programu za preprečevanje pokliene izgorelosti in spodbujanje zavzetosti za delo namenili modul, ki se ukvarja z organiziranostjo podjetja, in $\mathrm{s}$ tem $\mathrm{v}$ zvezi $\mathrm{z}$ regulacijo socialnih odnosov med pomembnimi nosilci podjetja.

\section{ANALIZA PODROČIJ DELA IN Z NIIMI POVEZANIH PSIHOLOŠKIH DELOVNIH OKOLIŠČIN}

Poklicno izgorelost poyzroča nenehen, četudi zmeren pritisk na delovnem mestu, pa naj izhaja iz odnosov ali poslovnih okoliščin. Vzrok za izgorelost je lahko tudi prevelik ob-

Iz besedil o poklieni izgorelosti pa tudi iz pripovedi poklicno izgorelih delavcev o tem, kaj jih je privedlo v to stanje, je mogoče izluščiti, da gre za psihološke delovne okoliščine, povezane $s$ šestimi področji dela $v$ podjetju: 1. delovno obremenitvijo, 2. nadzorom nad delom, 3, nagrado za opravljeno delo, 4. delovno skupnostjo, 5. pravičnostjo in 6. vrednotami (Leiter, Maslach, 2005). Je pa ta področja mogoče tudi vzeti pod drobnogled, poiskati izboljšave in ustvariti sistem posegov ter strategij za izboljšanje z njimi povezanih psiholoških delovnih okoliščin. Vseh šest področij je med seboj povezanih in vsa vplivajo na najvidnejše značilnosti poklicne izgorelosti: (I) čustveno izčrpanost, (2) jezo in prezir ter (3) neučinkovitost in neproduktivnost. 


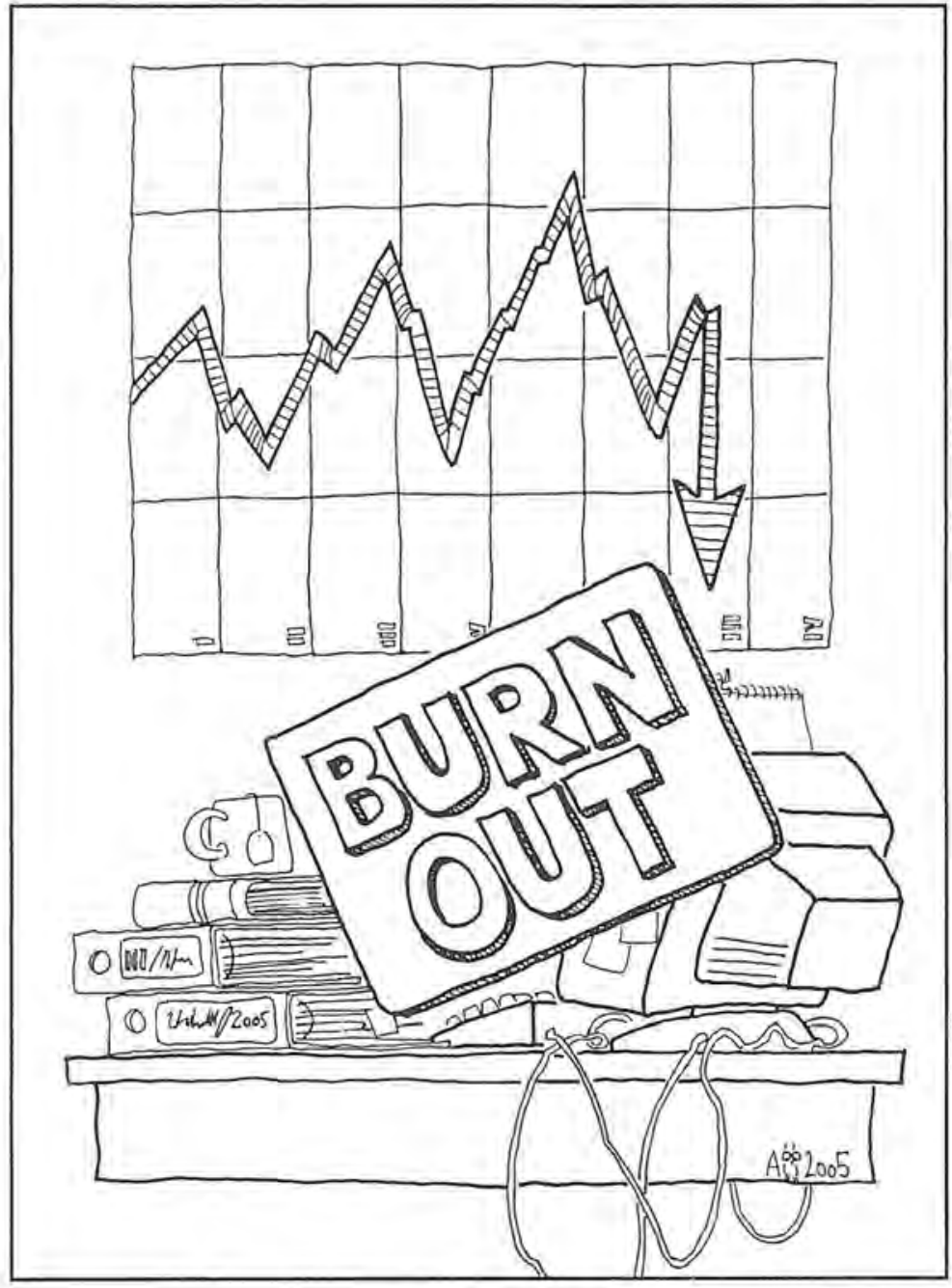

seg dela, pri čemer so lahko delovne naloge zahtevne in raznolike, a ker jih je preveč, ne budijo več zanimanja, marveč zgolj občutek monotonosti. Razumljivo. Mnogoštevilne delovne naloge nazadnje zaposleni doživijo podobno, kakor bi doživeli preveč preproste naloge; njihove pozornosti ne pritegnejo, zanje so le naporne.

Udeleženci izobraževanja za preprečevanje poklicne izgorelosti si tako zastavijo mnoga vprašanja v povezavi z zgoraj navedenimi področji dela. V povezavi z delovno obremenitvịjo, denimo, se sprašujejo o količini dela, ki ga morajo opraviti sleherni dan. Je ta ravno pravšnja, nekoliko prevelika, občutno preve- lika, morda tudi premajhna? Je delo zahtevno, je roke moč spreminjati ali ne, kolikšna je količina motenj na delovnem mestu, koliko časa preživijo v stiku s strankami in z drugimi sodelavci. S takšnimi in podobnimi vprašanji ozavestijo svoje doživljanje v povezavi z delovno obremenitvijo in prepoznajo tisto, kar bi morali spremeniti in popraviti ter iščejo načine, kako bodo to storili.

Glede na nagrado za delo se udeleženci sprašujejo, ali zaslužijo dovolj, ali imajo možnost napredovanja, v kolikšni meri imajo radi svoje delo, koliko časa preživijo na deIovnem mestu z ljudmi, ki so jim ljubi, itd. (Leiter, Maslach, 2005, str. 23-33). Podobna vprašanja si udeleženci postavijo tudi glede drugih področij dela, kjer se lahko pojavijo neugodne psihološke delovne okoliščine. Vsa ta in druga vprašanja so del analize njihovega položaja na šestih področjih dela v podjetju. Po opravljeni analizi udeleženci opredelijo problem. Če spoznajo, da se počutijo prezrti, zavedeni, negotovi in nemočni ter da nimajo nadzora nad svojim delom, vedo, zakaj se tako počutijo. Toga politika v podjetju in birokrati imajo moč nad njimi in tako se zdita njihova strokovnost in presoja prav malo vredni. Ko se nakopiči veliko ponavljajočih se neugodnih situacij, neizogibno sledi občutek nemoči. Pot v poklicno izgorelost je s tem tlakovana. Pomembno vprašanje $\mathbf{v}$ zvezi $\mathbf{z}$ nadzorom nad delom je na primer, koliko odločitev sprejemajo zaposleni skupaj z drugimi in koliko sami, kakšen je njihov položaj med sodelavci, koliko lahko vplivajo na odločitve o svojem delu, kako dobro je vodstvo podjetja, koliko lahko svobodno sledijo svoji strokovni presoji.

Udeleženci lahko $\mathrm{v}$ povezavi $\mathrm{z}$ nadzorom nad delom opredelijo tudi druge probleme. $\mathrm{Na}$ koščke razbito delo lahko prizadene polet zaposlenih, trdi Georges Friedmann (1964). Vsakdo namreč poskuša braniti samostojnost pri delu in pričakuje povratne informacije zanj. Brani jo pred predpostavljenimi in 
pred sodelavci. Problem je lahko tudi v tem, da predpostavljeni zaposlenim ne dovolijo, da delajo po svoje in jim določajo sleherni korak. ${ }^{7}$ Načrtujejo jim delovni dan. Vodijo jih, jih ocenjujejo, Namesto, da bi vse to počeli zaposleni sami. Posledica je zmanjšana zavzetost zaposlenih za delo in da prenehajo razvijati zmožnosti, ki jih imajo. Če takšno vodenje traja leta dolgo, lahko zaposlenega privede $v$ poklicno izgorelost.

Problem na področju nadzora nad delom so lahko tudi neučinkoviti vodje, neučinkoviti delovni timi ipd. Ni dovolj, da jih zaposleni preprosto prenašajo, dobro je, če tudi kaj storijo. Udeleženci izobraževanja za preprečevanje stanja poklicne izgorelosti torej najprej opredelijo problem v povezavi s posameznim področjem dela v podjetju. Č denimo spoznajo, da želijo imeti več nadzora nad delom, če spoznajo, da želijo odločati, uporabljati svoje spretnosti in znanje, doseči več in poseči dlje, če hočejo, da njihovi sodelavci upoštevajo njihovo mnenje, tedaj morajo tudi kaj spremeniti. Dobra rešitev nekaterih problemov z nadzorom nad delom je v ustvarjalnosti. Če spodbudimo nove akcije, nove projekte. Inovativnost je v podjetju velikega pomena, sicer se znajdemo sredi rutinskih opravil, kar vodi $v$ občutek frustriranosti. Tako je inovativnost zmeraj dobrodošla. Inovativni zaposleni so samostojnejši in imajo več nadzora nad delom. Nadzor nad delom dobimo tudi, če smo dovolj kritični ali če podpremo iniciative drugih. Navadno je to funkcija predpostavljenih. Če ti niso dobri vodje, pa lahko to storimo sami. Sodelavcem namenimo spodbudne besede, pozorni smo na njihove dosežke, skupaj z njimi se veselimo njihovega uspeha, izrazimo sočutje, če jim kaj ne uspe. Nadzor nad delom dobimo tudi tako, da se preverimo v očeh jaynosti, strank ipd. Lahko pa ga izgubimo navkljub temu, da smo dovolj kritični, močno ustvarjalni in spodbudni ... Tudi količina družbenih in gospodarskih sprememb ima lahko negativen vpliv. To se največkrat zgodi menedžerjem. Ti so namreč odvisni tudi od vseh zunanjih neugodnih okoliščin, $\mathrm{ki}$ se za nameček še hitro spreminjajo. Neprestano iskanje novih rešitev sredi procesov liberalizacije gospodarstva je lahko zelo naporno, če menedžerji ne vedo, kako ravnati s seboj in s svojimi potrebami. ${ }^{8}$ Udeleženci izobraževanja torej najprej opredelijo svoje razmerje do dela, nato prepoznajo probleme na posameznih

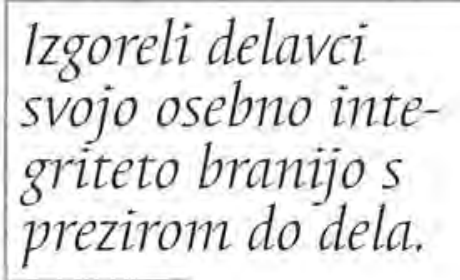
področjih dela, ki lahko ustvarjajo občutek nelagodja in neugodne psihološke okoliščine, ter po tistem iščejo rešitve zanje. Ob tem ozavestijo pot, po kateri lahko tonejo v stanje izgorelosti in jo poskušajo spremeniti.

\section{DOSEGANIE ZAVZETOSTI ZA DELO}

V svojem zadnjem delu Resnica o poklicni izgorelosti (The Truth About Burn-Out, 2005) je Christina Maslach, pionirska raziskovalka poklicne izgorelosti, uvedla novó tezo, ki jo velja preučiti. Njena trditev je, da je poklicna izgorelost na enem koncu daljice, medtem ko imamo na drugem koncu iste daljice njeno skrajno nasprotje - zavzetost za deló. Pravi, da ima poklicna izgorelost tri negativne razsežnosti: čustveno izčrpanost, prezir do dela in delovnega okolja ter neučinkovitost. Nasprotje tega pa je zavzetost za delo. Ta ima pozitivne označbe, kot so nenavadno velika energija, poglobljeno vživljanje $v$ delo in sodelavce ter velika učinkovitost.

Kdo: je zgorel, je brez energije. Priěne zamujati, čemi zvit v klobčič. Največkrat ure dolgo premišljuje, kako bo premaknil prst ali roko. Izgubi voljo. Vse mu je neznansko naporno, S prezirom se prilagaja in brani pred še večjimi pritiski. Prezir sicer kaže na to, da je človek še zmeraj povezan s svojim delom in delovnim okoljem, toda prezir se lahko konča z izgubo idealizma in v razělovečenih odnosih. Izgoreli

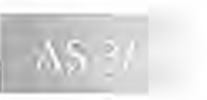


Rešitev za izgorelega posameznika je $v$ menjavi delovnega mesta, podjetja, celo $v$ menjavi poklicnega področja. To pa ni vsakomur dano. Zato poklicno izgorela oseba ob tem potrebuje veliko podpore, svetovanja in spremljanja (coaching). Pri tem ne gre za preprosto načrtovanje poklicne poti (career planning), kakršnega poznamo $\mathrm{v}$ izobraževanju odraslih. To ni svetovanje za načrtovanje življenjske poti (nem. Lebens Beratung). To ni zgolj psihološko svetovanje. Pogosto potrebuje izgorela oseba tudi pravne in poslovne nasvete, psihoterapijo, družinsko terapijo itd. Svetovalec izgoreli osebi mora imeti izjemno širok referenčni okvir. ${ }^{9}$

človek se bo s prezirom branil in ne bo več dal veliko od sebe, če bo ostal na istem delovnem mestu. Njegova legendarna delovna učinkovitost se sprevrže v navidezno delo. Morda je na videz še zmeraj učinkovit, morda za druge je učinkovit, zase ne.

Avtorici tega članka ugotavljava, da bi veljalo razmejiti motiviranost za delo in zavzetost za delo ter tako še bolj poudariti, da so za delo zavzeti oni, ki jim ni toliko pomemben cilj dela, marveč delo samo oziroma pot do cilja. Zavzetost za delo je lastnost, ki ni povezana zgolj s posameznim delom, marveč se pojavi

Poklicno izgorelost moramo šteti med poklicne bolezni. ob kakršnemkoli delu. ${ }^{10}$ Zavzetosti za delo tudi ne smemo zamenjati $s$ tradicionalnim konceptom zadovoljstva pri delu, zvestobe delovini organizaciji. Zadovoljstvo z dobro opravljenim delom je nekaj zelo ozkega $\mathrm{v}$ primerjavi z delovno zavzetostjo in se tudi to nanaša samo na cilj dela. Zavzetost za delo pa nas vodi v neprestano premišljanje o vsem, kar doživimo, in o načinih, kako opravljamo neko delo, o poti do cilja. Vse znamo povezati $\mathrm{z}$ delom, v vsem vidimo izziv, "Preučevanje okoliščin, ki nas vodijo v poklicno izgorelost, nas je navedlo tudi na preučevanje, kako pri zaposlenih razvijati zavzetost za delo tako $\mathrm{v}$ dobro zaposlenih kakor tudi podjetja.

\section{PRAVNA PODLAGA ZA OBRAVNAVO POKLICNE IZGORELOSTI}

Namen enega od jedrnih vsebinskih modulov programa je povečati ozaveščenost vodstva podjetij in zaposlenih o pravnih posledicah poklicne izgorelosti. V nekaterih evropskih državah zaposleni lahko vložijo zahtevek za nadomestilo povzročene škode. Iz teh zahtevkov je razvidno, kako veliki so stroški podjetja in države, ko je poklicna izgorelost že tu, Tisto, kar najlaže izmerimo, so stroški z dolgotrajno, najmanj leto trajajočo odsotnostjo z dela.

Sindrom poklicne izgorelosti združuje vrsto različnih simptomov, med njimi simptome depresije. Ce ga obravnavamo le kot depresijo, bo z njim v zvezi težko doseči ustrezno pravno regulacijo. Poklicna izgorelost je trajna poškodba, ki jo povzročijo neugodne psihološke okoliščine na delovnem mestu. Hkrati $v$ prefrontalnem delu možganov nastanejo lezije. Najverjetneje se posledično za dolgo časa ali trajno spremeni izločanje kortizola, spremenijo se adrenalinske reakcije, spremeni se naša odzivnost na neugodne psihološke okoliščine. ${ }^{12}$ Človek, ki je šel skozi skrajno stopnjo poklicne izgorelosti, potrebuje nenavadno dolgo časa, da si opomore že po majhnih situacijah, ki ga prizadenejo; nepredvidene dodatne zadolžitve, neustrezni delovni pogoji, neizvedljivost dela $\mathrm{v}$ določenem času, vsakodneven in intenziven pritisk na delovnem mestu, neprimerno okolje. ${ }^{13}$ Gre torej za poškodbo na delovnem mestu. ${ }^{14}$ Uveljavljati bi jo bilo mogoče le na podlagi preučitve odnosov med človekom in delovnim okoljem. Ne glede na to, da je po opredelitvi Svetovne zdravstvene organizacije tudi psihično ravnovesje del zdravja, pa so v slovenski zakonodaji 
predvidene le telesne poškodbe na delovnem mestu. Danes, ko so ustrezni psihološki pogoji dela pomemben dejavnik varnosti pri delu, bi morali tudi psihiěne poškodbe, ki nastanejo zaradi dela, obravnavati kot takšne. V francoski zakonodaji, denimo, je to že mogoče.

Izobraževanje, spremljanje in svetovanje na področju poklicne izgorelosti bi tako moralo biti tudi pravne narave. Dokler pa poklicne izgorelosti in njenih posledic ne bomo zajeli v določila zakona, za ustrezno varstvo pri delu, ki se nanaša na psihološke delovne pogoje, ne bo poskrbljeno. Prav tako bo bolj malo zakonske podlage za tovrstno izobraževanje. V Resoluciji o nacionalnem programu varstva pri delu je sicer govor o vse večji razširjenosti stresa na delovnem mestu in njegovih posledicah, izražena je potreba po ustanovitvi inštituta za preučevanje pojava. Poklicna izgorelost pa je že obravnavana kot kronična psihološka poškodba v nekaterih drugih dokumentih, denimo v Resoluciji Evropskega parlamenta o spodbujanju zdravja in varnosti na delovnem mestu, 2004/2205INI.

\section{SKLEPNA BESEDA}

Poklicno izgorelost (burn-out) opredeljujemo kot psihološki sindrom pa tudi kot kronično psihološko poškodbo, ki je kumulativni odgovor na dolgotrajne neugodne psihološke delovne okoliščine, na pritiske $v$ medsebojnih odnosih. Poklicno izgorelost lahko preprečimo $\mathrm{z}$ znanstveno utemeljeno organiziranostjo podjetja, ki naj bo takšna, da spodbuja ustrezne formalne in neformalne komunikacijske okoliščine v podjetju in spodbudne medsebojne odnose. Izobraževanje za prepoznavanje in preprečevanje poklicne izgorelosti in hkrati za razvoj zavzetosti za delo je namenjeno tako posamezniku kakor tudi vsemu podjetju, pa tudi socialnim partnerjem, zakonodajalcem, strokovni in širši javnosti. Ima jedrne module in module, ki so namenjeni posameznikom in posameznim ciljnim skupinam glede na pred- hodno analizirane skupne potrebe.

Med jedrne module se po izsledkih te raziskave uvrščajo (1) prepoznavanje poklicne izgorelosti, njenih vzrokov, simptomov in posledic, (2) vpliv organiziranosti podjetij in drugih ekonomskih struktur na medsebojne odnóse in komunikacijske delovne okoliščine, (3) analiza področij dela in z njimi povezanih psiholoških okoliščin, (4) doseganje zavzetosti za delo pri zaposlenih in (5) pravna podlaga za obravnavo poklicne izgorelosti. Ustrezne psihološke okoliščine $\mathrm{v}$ podjetju ustvarjamo $\mathrm{z}$ regulacijo socialnega sistema odnosov med nosilci podjetja. Ustrezne psihološke deloyne okoliščine (priložno-
Poklicno izgorevanje lahko z izobraževanjem zelo omilimo, če ne že povsem preprečimio. sti za komunikacijo, postopki sprejemanja odločitev, dajanja vrnitvenih informacij, itd.) so podlaga za ustvarjanje, vzdrževanje in spodbujanje zavzetosti za delo, kar naredi podjetje konkurenčnejše.

Za ozaveščanje široke javnosti o poklicni izgorelosti je poleg običajnih izobraževalnih kanalov in oblik, kot so radijske in televizijske oddaje, okrogle mize, predavanja, naročena sporočila po mobilnem telefonu itd., potrebno ustvariti predvsem spletno stran, kjer obiskovalci lahko izvedo temeljna dejstva o poklicni izgorelosti, se pridružijo pogovorni skupini, najdejo novice o obvladovanju poklicne izgorelosti, naredijo svoj psihološki in delovni profil, primerjajoč svoj začetni profil s kontrolnim profilom. Stran mora biti namenjena tudi podjetjem, ki želijo oplemeniti svoj najpomembnejši vir: ljudi. Spletna stran ima namen spodbuditi nastanek skupnosti, ki si želi delati boljše in $v$ boljših psiholoških okoliščinah.

\section{LITERATUIRA IN VIRI}

Baudelot, C., Gollac, M., idr. (2003). Travailler pour étre hetreux. Le bohneur et le travail en France. Pariz:

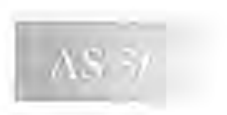


Fayard.

Beaud, S., Pialoux, M. (1999). Retour sur la condition ouvrière. Enquête aux usines Sochaux de Montbéliard. Pariz: Fayard.

Boltanski, L., Chiapello, E. (1999). Le nouvel esprit du capitalisme. Pariz: Gallimard.

Doron, R., Parot, F. (1991). Dictionnaire de psychologie. Pariz: PUF, str. 126.

Findeisen, D. (2003). Identiteta, spoštovanje samega sebe in učljivost. Andragoška spoznanja, 9/4, str. 3-4.

Friedmann, G. (1964). Le travail en miettes- Spécialisation et loisirs. Pariz: Gallimard.

Gallerman, S. W. (1967). Les relations humaines dans la vie de l'entreprise. Editions d'organisations, Pariz.

Lahire, B. (1998). L'homme pluriel. Les ressorts de l'action. Pariz: Nathan.

Leiter, M. P., Maslach, C. (2005), Banishing Burnout, six strategies for improving your relationship with work. San Francisco: Jossey Bass.

Maruani, M. (2000). Travail et emploi des femmes. Paris: La Découverte.

Reynuud, J. D. (1960). Traité de sociologie du travail. Puriz: Gallimard, str. 74.

Sainsaulieu, R. (1988). L'identité au travail, Presses de la Fondation nationale des sciences politiques, Pariz.

Sennett, R. (1999). The Corrosion of Character. New York, London: W. W. Norton \& Company.

Taylor, F. W. (1967). The Prineiples of Scientific Managment. New York; Harper and Row.

\footnotetext{
Francoski Telecom in podjetje Hurchinson imata delovno mesto wdirektorja sreče in dobrega počutja». IBM je objavil seznam 160 podjetij, kjer se zaposleni najbolje počutijo.

${ }^{2}$ Andiej Studen: Stanovati v Ljubljani.

${ }^{3} \mathrm{~V}$ osverlitev te Irditve navajano primer vodje proizvodnje, ki je zrasel s swojim podjetjem in je veljal za izjemno zavzerega za delo. V pogovoru ga je opisal kot svojo hišo, svoj dom, kjer vladajo neki zakoni in navade. Dolga lera je odhajal na delo popevajoč. Veselili so ga odnosi s sodelavci. Med njimi je imel prijatelje. Z internacionalizacijo podjerja se je na mestu direktorja znašel "Holandec*, kot so ga poimenovali zaposleni. Govoril je le anglesko. Bil je solan in podjetje je preoblikoval po sodobnih pravilih menedžmenta. Kaj se je v podjetju dogajalo prej, ga ni zamimalo. Od takrat dalje je naš sogovornik tonil y depresijo. Zrušil se mu je svet, skaterim se je povsem istovetil.

t Doron R., Parot, F. (1991). Dictionnaire de psychologie, PUF, Paris, str. 126.

${ }^{5}$ Baudelot in drugi so ugotovili, da so rednore zensk dingačne od wrednor moških glede dela, ki ga oprayljajo. Ženske si želijo imeti predusem zanimivo delo in primerne delovne urnike, moški predusem oblast in denar. Ustrarjati ugodne psiholoske okoliscine na delowem

mestu mora tako temeljiti na ugotavljanju wednot zaposlenih. Te so različne glede na izobrazbo, spol, starost (Baudelot in drugi, 2003).

' $S$ prihodom nujih imestitorjen zaradi pomanjkanja sobčntljiwosti za diuge kulture prihaja do sbrisanjax mentalnih, kultumih in kolektivnih navad zaposlenib. Z odpušcanjem zaposlenih nastaja pri zaposlenih dvojni socializacijski proces, ki vodi y navidez prilagojeno obnašanje ... Lažni jaz pa je vir stresa.

7Gre za mikro-menedžnient.

s Ob vdoru korejskih proizudow na francoski thg so se posamezni menedžerji različno odzvali. Tisti, manj utrujeni od večnih borb in sprememb, so ugotovili, da se bodo wăili tujih kulur in odšli na svetomi trg. Oni, ki jim je bilo že vsega dovolj. so doživeli še en močan stres več. Liberalizacija gospodarstva, združevanje podjetij, premikanje pristojnosti itd. so neugodne psihološke delovne okoliščne, ki jih ni lahko prenesti.

${ }^{9}$ To pomeni, da najverjetneje potrebujemo nove poklicne profile svetovalcev izgoreliut osebain.

10 „Piav veeno je bilo, česa sem se lotila, we the je cez čas enako prilegnilo. Inela sem izrazito nagnjenje do problemskega učenja in do učenja, ki bi izboljšsalo polożaj drugih ljudiк, je povedala D. F.

"I Ob pregledu kanadskih izobraževalnih filmov o poklicni izgorelosti smo naleteli na izjave, kot so wPrav vse je bilo podrejeno delu. Bil sem na počitnicah, bral sem leposlovno knjigo in že so se mi porajale zamisli, kaj vse bi se lahko naredil v swojem podjetju. Nikoll nisem kosil sam, zmeraj je bilo moje kosilo poslovno kosilo. Šel sem po hodniku in sleherno srečanje se je spremenilo v daja. nje navodil sodelavcem ... V pisarni sem imel zofo, kamor sem se zleknil za deset minut in potonil v spanec ... Kadar sem odšel na počitnice, sem nestrpno čakal konca, da sem 'odkljukal' tudi to 'dolžnost', Zjutraj sem se prebujal z mislijo na dianajst ali več razliěnih dolžnosti v dnevu. Zmeraj mi je na koncu dneva kakšna ostala ... In tako iz dneva $\mathrm{v}$ dan, iz leta v leto ...

${ }^{12}$ Ena od avtoric tega članka je povedala: „Kadar naletim na poznane neugodne psihološke okoliščine, denimo v.starem delomem okolju, mi postane slabo. Prič̀mem se tresti, postanem prezirljiva. Vnovih okoliščinah takšnih odsivov ni, vendar tudi čustev navdušenja ali zalosti ni več ....

13 Zakon o pokojninskem in invalidskem zavarovanju (Ur: l, RS, st. 26/2003)

${ }^{4}$ Loi sur les accidents du travail et les maladies professionnelles, slov. Zakon o poškodbah na delu, poklicnih boleznih - člen 2, avgust 1985, določa, da pri delu lahko nastaneta tudi psihični spoklicna poškodba ali poklicna bolezen . Poškodba na delu je po tem zakonu posledica nepredvidenega nenadnega dogodka, poklicna bolezen pa je posledica dolgotrajnejših okolišcin in tvegani na delopnem mestu. 